\title{
Useful Intermediates, 3- $C$-Dichloromethyl Furanose Derivatives, for the Synthesis of Branched-Chain Functionalized Sugars
}

\author{
Ken-ichi Sato, ${ }^{*}$ Katsuhiko Suzuki, Miyuki Ueda, Yasuhiro Kajihara, and Hiroyuki Hori \\ Laboratory of Organic Chemistry, Faculty of Engineering, Kanagawa University, \\ Rokkakubashi, Kanagawa-ku, Yokohama 221 \\ (Received July 19, 1996)
}

\begin{abstract}
A few novel branched-chain functionalized sugars, which have important functions such as hydroxy, hydro, chloro, or azido at the quaternary carbon, were stereoselectively prepared in good yield via the same intermediary 3-C-,3-Ochloromethylene- or 3-C-dichloromethyl-1,2:5,6-di- $O$-isopropylidene- $\alpha$-D-furanose derivatives.
\end{abstract}

Numerous new branched-chain sugars as the glycosidic component of antibiotics during the past two decades have stimulated extensive research on the chemistry and biochemistry of sugars. Most of the branched-chain sugars found in nature have a polar substituent at the branching carbon-atom (Type A); tertiary alcohols are the most common, and in several instances an amino or nitro group is attached to the branching carbon atom. In a few cases naturally occurring branched-chain sugars have no substituent at the branching carbon atom (Type B). In general, various branched-chain sugars have been synthesized by applying a Grignard reaction, Reformatsky reaction, Wittig reaction as well as organolithium, nitromethane, diazomethane, and cyanohydrin syntheses to suitable glycosidulose. ${ }^{1)}$ In 1988, Thang et al. ${ }^{2)}$ reported an elegant approach for synthesizing branched-chain sugars using chloromethyl p-tolyl sulfone. In 1969, Köbrich et al. $^{3)}$ reported that the reaction of a 2,2-dichloroethanol derivative with $\mathrm{KOH}$ gave an 2-hydroxy aldehyde derivative in good yield via the corresponding spiro chlorooxirane derivative. In that report, ring opening with the hydroxide anion was described as seeming to occur with complete regiospecificity at the $\beta$-carbon with respect to the chloro group (Scheme 1). Unfortunately, they did not discuss the stereochemical course of this reaction. The authors were inspired by Köbrich's work in constructing any type of naturally occurring functionalized branched-chain sugars, and tried to study the stereochemical course of this reaction.

In a previous paper, ${ }^{4)}$ the authors communicated on a facile and effective simple reagent, dichloromethyllithium, for the synthesis of various functionalized branched-chain sugars, which were easily converted into almost all types of naturally occurring types. This paper describes the details concerning the communication, additional new data, as well as a suggestion concerning the stereochemical course of Köbrich's work using 3-C-dichloromethyl-1,2:5,6-di- $O$-isopropylidene- $\alpha$ D-allofuranose (3) (Scheme 2).

\section{Results and Discussion}

The reaction of 1,2:5,6-di- $O$-isopropylidene- $\alpha$-D-ribohexofuranos-3-ulose $(\mathbf{1})^{5)}$ with dichloromethyllithium (2.0 mol amt.) in oxolane at $-78{ }^{\circ} \mathrm{C}$, subsequently quenched with a saturated ammonium chloride solution, gave the corresponding dichloromethyl derivative (3) in $88 \%$ yield via 2. On the other hand, the reaction mixture was worked up after heating at $65^{\circ} \mathrm{C}$ to give $3,1^{\prime}$-anhydro-3-C-( $1^{\prime}$-chloro$1^{\prime}$-hydroxymethyl)-1,2:5,6-di- $O$-isopropylidene- $\alpha$-D-allofuranose (5) in $94 \%$ yield via 2 . Compound $\mathbf{5}$ was also derived from 3 by a treatment with 1,8-diazabicyclo[5.4.0]undec-<smiles>[R]C([2H])=O</smiles><smiles>[R]C([2H])([18OH])CC</smiles><smiles>C[C@H](O)[Co]</smiles><smiles>[2H]C([2H])(O)C(Cl)Cl</smiles><smiles>[R]C([R])(Cl)C=O</smiles><smiles>[R]C1([R])O[C@@H]1Cl</smiles><smiles>CCO</smiles><smiles>[R]C([R])(O)C=O</smiles>

Scheme 1 . 


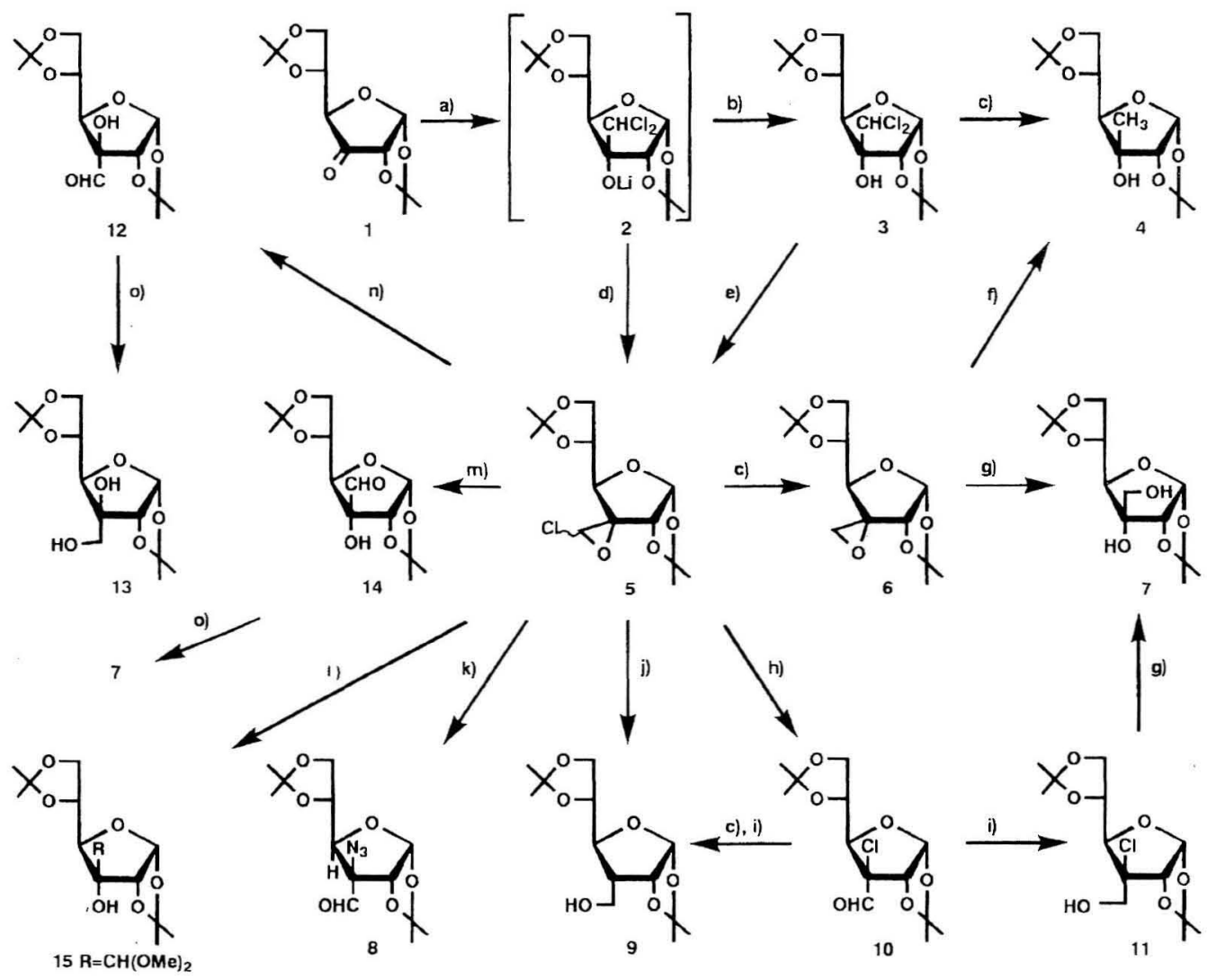

Scheme 2. a) $\mathrm{LDA}, \mathrm{CH}_{2} \mathrm{Cl}_{2}$, oxolane, $-78^{\circ} \mathrm{C}$ b) $\mathrm{H}_{2} \mathrm{O}$, r.t. c) $n-\mathrm{Bu}_{3} \mathrm{SnH}$, $\mathrm{AIBN}$, toluene, reflux. d) $65^{\circ} \mathrm{C}$. e) $\mathrm{DBU}$, DMSO, r.t. f) $\mathrm{LiAlH}_{4}$, oxolane, r.t. g) $\mathrm{NaOH}$ aq, 1,4-dioxane, reflux. h) $\mathrm{NaOAc}, 15$-crown-5, HMPT, $70{ }^{\circ} \mathrm{C}$. i) $\mathrm{NaBH}_{4}$, aq $\mathrm{MeOH}$, r.t. j) $\mathrm{NaBH}_{4}$, DMSO, $80{ }^{\circ} \mathrm{C}$. k) $\mathrm{NaN}_{3}, 15$-crown-5, HMPT, $70{ }^{\circ} \mathrm{C}$. l) $\mathrm{NaOMe}, \mathrm{HMPT}, 70{ }^{\circ} \mathrm{C}$. m) $n$ $\mathrm{Bu}_{4} \mathrm{NOH}$ aq, DMSO, r.t. n) CsOAc, 18-crown-6, toluene, reflux. o) $\mathrm{NaBH}_{4}, \mathrm{MeOH}$, r.t.

7-ene (DBU) in dimethyl sulfoxide (DMSO) in $82 \%$ yield. The configuration of 3 was confirmed by a derivation into a known 3-C-methyl derivative, $1,2: 5,6$-di- $O$-isopropylidene3 - $C$-methyl- $\alpha$-D-allofuranose $(4)^{6)}$ in $87 \%$ yield by radical reduction [tributyltin hydride, $2,2^{\prime}$-azobis(isobutyronitrile) $(\mathrm{AIBN}) /$ toluene]. The structure of $\mathbf{5}$ was also confirmed by derivation into $3,1^{\prime}$-anhydro-3- $C$ - $\left(1^{\prime}\right.$-hydroxymethyl)$1,2: 5,6$-di- $O$-isopropylidene- $\alpha$-D-allofuranose $(6)^{7)}$ with tributyltin hydride and AIBN in $81 \%$ yield. Compound 6 is difficult to synthesis by the previously used common methods (a reaction of 1 with diazomethane or oxidation of the 3$C$-methylene derivative of $\mathbf{1}$ with $m$-chloroperbenzoic acid) owing to the ring expansion and/or reverse stereoselectivity. An alkali hydrolysis of $\mathbf{6}$ gave the corresponding hydroxymethyl derivative, 3- $C$-hydroxymethyl-1,2:5,6-di- $O$-isopropylidene- $\alpha$-D-allofuranose $(7),{ }^{8)}$ in quantitative yield. Compound 6 was treated with lithium aluminum hydride $\left(\mathrm{LiAlH}_{4}\right)$ to also give the 3 - $C$-methyl derivative 4 in $83 \%$ yield. Kirrmann et al. ${ }^{9)}$ reported that chlorooxiranes can be obtained from the 2,2-dichloroethanol derivatives by a treatment with alkali under carefully chosen conditions (Scheme 1). The reaction of $\mathbf{3}$ with nucleophiles seems to easily progress via 5 under the reaction conditions, because both reactions 3 and 5 give the same products and almost the same yield. It is therefore possible to use $\mathbf{3}$ instead of $\mathbf{5}$ in reactions with nucleophiles. A treatment of $\mathbf{3}$ or $\mathbf{5}$ with $\mathrm{NaN}_{3}$ (10 mol amt.) and 15 -crown-5 in hexamethylphosphoric triamide (HMPT) at $70{ }^{\circ} \mathrm{C}$ gave 3-azido-3-deoxy-3- $\mathrm{C}$-formyl-1,2:5,6-di- $O$ isopropylidene- $\alpha$-D-glucofuranose (8) in $81 \%$ (from 3 ) and $85 \%$ (from 5) yield, the configuration of which was supported by NMR (NOE; $10 \%$, between formyl proton and $\mathrm{H}-$ 4 proton). Compound 8 is easily derived into the 3 -amino-3deoxy-3-C-methyl branched-chain sugar, which has usually been synthesized by the long steps from 1 (via cyanohydrin and spiro epimino derivative). The 3-deoxy derivative, 3deoxy-3- $C$-hydroxymethyl-1,2: 5,6-di- $O$-isopropylidene- $\alpha$ D-allofuranose (9) was derived by reducing 3 with $\mathrm{NaBH}_{4}$ in DMSO at $80^{\circ} \mathrm{C}$ in $65 \%$ yield. The structure of 9 was clarified by acetylation (acetyl derivative of $9:{ }^{1} \mathrm{H}$ NMR $J_{2,3}=4.6 \mathrm{~Hz}$, $J_{3,4}=10.0 \mathrm{~Hz}$ ). Compound 9 has usually been synthesized by hydroboration of the corresponding 3-C-methylene derivative of $\mathbf{1}$. The reaction of $\mathbf{3}$ with $\mathrm{NaOAc}$ ( $10 \mathrm{~mol}$ amt.) and 15-crown-5 in HMPT at $70{ }^{\circ} \mathrm{C}$ gave an unexpected chlorinemigrated product, 3-chloro-3-deoxy-3- $C$-formyl-1,2:5,6-di$O$-isopropylidene- $\alpha$-D-glucofuranose (10) instead of a tertiary acetoxy derivative, in $83 \%$ yield. Kirrmann et al. also reported ${ }^{9)}$ on a rearrangement of the alkoxides into 2-chloro aldehydes, which proceeds via the unstable chlorooxiranes 

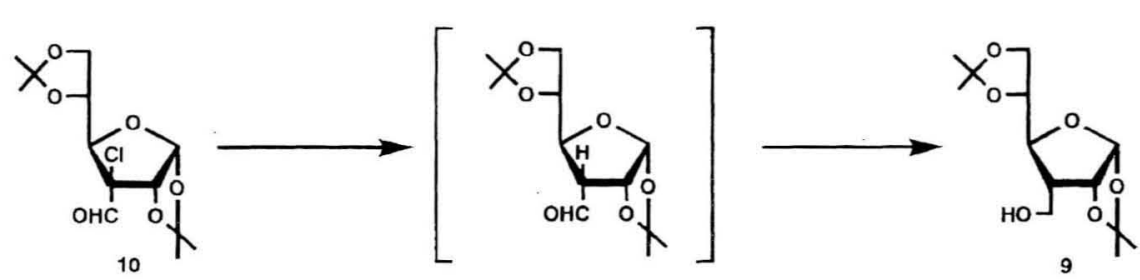

Scheme 3.
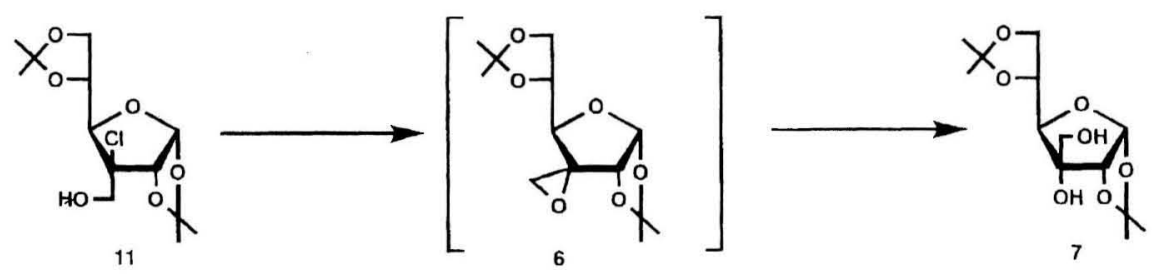

Scheme 4.

(Scheme 1). The structure of $\mathbf{1 0}$ was confirmed as follows. A radical reduction of $\mathbf{1 0}$ with tributyltin hydride in toluene at $110^{\circ} \mathrm{C}$ gave 3-deoxy-3- $C$-formyl-1,2:5,6-di- $O$-isopropylidene- $\alpha$-D-allofuranose in the form of a hydrate, which was reduced (without purification) with $\mathrm{NaBH}_{4}$ in $\mathrm{MeOH}$ at room temperature to give the corresponding 3-deoxy derivative 9 in $82 \%$ yield ( 2 steps) (Scheme 3 ). On the other hand, a hydride reduction of $\mathbf{1 0}$ with $\mathrm{NaBH}_{4}$ in $\mathrm{MeOH}-\mathrm{H}_{2} \mathrm{O}(2: 1)$ at room temperature gave 3-chloro-3-deoxy-3-C-hydroxymethyl-1, $2: 5,6$-di- $O$-isopropylidene- $\alpha$-D-glucofuranose (11) in $97 \%$ yield. The structure of $\mathbf{1 1}$ was clarified by a derivation into its acetyl derivative. Compound $\mathbf{1 1}$ was then treated with 0.1 $\mathrm{M} \mathrm{NaOH}\left(1 \mathrm{M}=1 \mathrm{~mol} \mathrm{dm}^{-3}\right)$ in 1,4-dioxane- $\mathrm{H}_{2} \mathrm{O}(1: 1)$ under reflux conditions to give 7 via 6 in $70 \%$ yield (Scheme 4). It seemed that the reactivity of $\mathrm{NaOAc}$ was not sufficient to compare it with that of the other nucleophiles. Therefore, the authors tried to use more effective $\mathrm{CsOAc}^{(0)}$ instead of $\mathrm{NaOAc}$, as follows. Compound 3 was treated with $\mathrm{CsOAc}$ (10 mol amt.) and 18-crown-6 (7.0 mol amt.) in toluene under reflux conditions to give the corresponding unstable 2hydroxy aldehyde, 3- $C$-formyl-1,2 : 5,6-di- $O$-isopropylidene$\alpha$-D-glucofuranose (12), in $36 \%$ yield. Compound 12 easily formed its hydrate via the corresponding 3-acetoxy derivative (accompanied by a cleavage of the acetyl group), but was too unstable to purify. It is noteworthy that this type of acetyl group seems to be easily cleaved by a weak base. ${ }^{(1)}$ The configuration of 12 was confirmed by derivation into 3-epimer of 7,3- $C$-hydroxymethyl-1,2:5,6-di- $O$-isopropylidene- $\alpha$-Dglucofuranose $(\mathbf{1 3}){ }^{8)}$ On the other hand, the reaction of $\mathbf{3}$ with $n-\mathrm{Bu}_{4} \mathrm{NOH}$ ( $40 \%$ in water, $5.2 \mathrm{~mol}$ amt.) was carried out in DMSO at room temperature for a short time (30 s), and the epimeric 2-hydroxy aldehyde, 3-C-formyl-1,2:5,6di- $O$-isopropylidene- $\alpha$-D-allofuranose (14), was obtained in $61 \%$ yield. Since compound $\mathbf{1 4}$ was also too unstable to purify, its structure was confirmed by derivation into 7 by a treatment with $\mathrm{NaBH}_{4}$ in $\mathrm{MeOH}$, of which the physical data were identical with that obtained from 6. Although compound $\mathbf{1 4}$ has usually been synthesized by the reaction of $\mathbf{1}$ with nucleophiles, such as vinyl or bis(alkylthio)methyl derivatives, its epimer $\mathbf{1 2}$ has been difficult to synthesis, due to its reverse stereoselectivities. In contrast to the above reaction using $n-\mathrm{Bu}_{4} \mathrm{NOH}$, the reaction of 3 with $\mathrm{NaOMe}(10$ mol amt.) in HMPT at $70{ }^{\circ} \mathrm{C}$ gave 3 - $C$-dimethoxymethyl$1,2: 5,6$-di- $O$-isopropylidene- $\alpha$-D-allofuranose (15) in $93 \%$ yield. The branched-chain sugars $(8,9,10,12$, and 14) have useful functions, such as azido, hydro, chloro, or hydroxy, at the quaternary carbon, and are converted to branched-chain sugars of type A and B, respectively (Scheme 2). Among the above-mentioned functional groups, the azido group can be easily converted into an amino or nitro group, and the formyl group can be converted into a hydroxymethyl, methyl, 1-hydroxyethyl, acetyl, 2-hydroxyacetyl, 1,2-dihydroxyeth$y l$, high alkyl, or carboxyl group, all of which are found in nature.

In conclusion, the ring opening of spiro chlorooxirane with a nucleophile, such as $\mathrm{N}_{3}^{-}, \mathrm{H}^{-}, \mathrm{Cl}^{-}$(NaOAc, 1,2migration of chlorine), or $\mathrm{AcO}^{-}$(CsOAc), occurs with complete regiospecificity and $\mathrm{S}_{\mathrm{N}} 2$ fashion at the $\beta$-carbon with respect to the chloro group. However, in the case of $\mathrm{OH}^{-}$ or $\mathrm{OMe}^{-}$, the reaction occurs at the $\alpha$-carbon. The different regiospecificity may be attributed to the reactivities of nucleophiles to this type of epoxide. That is, nucleophiles such as $\mathrm{OR}^{-}, \mathrm{OH}^{-}$, and $\mathrm{SR}^{-}$, having a strong nucleophilicity (nearly equal to strong base), react at the $\alpha$-carbon, which has a lower electron density than that of the $\beta$-carbon. In the case of weak nucleophiles (their conjugate acids are rather stronger), the epoxy oxygen first coordinates to acid; the reaction then proceeds via the favorable $\beta$-carbenium intermediate (stabilized by two alkyl groups) rather than the $\alpha$-carbenium intermediate (destabilized by chlorine). Of course, even the $\beta$-carbenium ion is not sufficiently stable to react in $S_{N} 1$ fashion. As mentioned above, these results may provide an answer regarding the stereochemical course of Köbrich's work ${ }^{3)}\left(\mathrm{OH}^{-}\right.$reacts at $\alpha$-carbon or $\beta$-carbon with respect to the chloro group), which did not consider the configurations of the products. Thus, the method proposed herein may promise wide applications to the preparation of functionalized branched-chain sugars whose branching car- 
bon is on the sterically hindered side. Especially, two modes of reactions of the 3-C-dichloromethyl furanose derivative, or the corresponding spiro chlorooxirane, either with $\mathrm{CsOAc}$ or with $n-\mathrm{Bu}_{4} \mathrm{NOH}$ may provide a convenient method for the selective preparation of each epimeric 2-hydroxy aldehyde derivative.

\section{Experimental}

All melting points were uncorrected. The solutions were evaporated under reduced pressure at a bath temperature not exceeding $40^{\circ} \mathrm{C}$. The optical rotations were measured in a $0.5 \mathrm{dm}$ tube with a JASCO DIP-140 polarimeter in chloroform. 'H NMR spectra were recorded in chloroform- $d$ with a JEOL EX-90, FX-200, EX-270, or A-500 spectrometer. IR spectra were recorded with a Hitachi 270-30 spectrometer. Elemental analyses were performed on a Perkin-Elmer $240 \mathrm{C}$ or $2400 \mathrm{II}$ elemental analyzer. The chemical shifts, coupling constants, and IR frequencies were recorded in $\delta, \mathrm{Hz}$, and $\mathrm{cm}^{-1}$ units, respectively. Column chromatography was performed on silica gel (Silica gel 60, 70-230 mesh, Merck). Thin-layer chromatography (TLC) on silica gel (Silica gel $60 \mathrm{~F}_{254}$, Merck) was used to monitor the reactions and to certify the purity of the reaction products.

1,2 : 5,6-Di- $O$-isopropylidene-3- $C$-dichloromethyl- $\alpha$-D-allofuranose (3). To a stirring solution of diisopropylamine $(770 \mathrm{mg}$, $7.61 \mathrm{mmol})$ in oxolane $\left(100 \mathrm{~cm}^{3}\right)$ was added butyllithium $(1.64 \mathrm{M}$ solution in hexane, $\left.4.8 \mathrm{~cm}^{3}, 7.87 \mathrm{mmol}\right)$ at $-78^{\circ} \mathrm{C}$ under argon, and stirred for $30 \mathrm{~min}$; then, abs dichloromethane $(3.24 \mathrm{~g}, 38.1 \mathrm{mmol})$ in oxolane $\left(5.0 \mathrm{~cm}^{3}\right)$ was added dropwise for $3 \mathrm{~min}$ and stirred for $3 \mathrm{~min}$. To the above reaction mixture, $1,2: 5,6$-di- $O$-isopropylidene- $\alpha$-D-ribo-hexofuranos-3-ulose $(\mathbf{1})^{5)}(982 \mathrm{mg}, 3.80 \mathrm{mmol})$ in oxolane $\left(10.0 \mathrm{~cm}^{3}\right)$ was added dropwise for $5 \mathrm{~min}$ and stirred until the disappearance of $\mathbf{1}$ on TLC (hexane/ethyl acetate $=2 / 1$ ). The reaction mixture was poured into a saturated ammonium chloride solution, extracted with chloroform $\left(100 \mathrm{~cm}^{3} \times 1,10 \mathrm{~cm}^{3} \times 5\right)$, washed with brine $\left(20 \mathrm{~cm}^{3} \times 2\right)$, dried over anhydrous magnesium sulfate, and evaporated to give a residue. The residue was purified on a column of silica gel (hexane/ethyl acetate $=3 / 1-2 / 1$ ) to give 3 $(1.15 \mathrm{~g}, 88 \%$ yield), which was recrystallized from ether-hexane. $\mathbf{3}$ : $\mathrm{Mp} 134-135^{\circ} \mathrm{C}$ (recrystallized from $\mathrm{Et}_{2} \mathrm{O}$-hexane); $[\alpha]_{\mathrm{D}}^{24}+27.7^{\circ}$ (c 1.0, $\mathrm{CHCl}_{3}$ ); IR $3476 \mathrm{~cm}^{-1}(\mathrm{OH}) ;{ }^{1} \mathrm{HNMR}$ (FX-200) $\delta=6.23$ $\left(1 \mathrm{H}, \mathrm{s}, \mathrm{H}-3^{\prime}\right), 5.93\left(1 \mathrm{H}, \mathrm{d}, J_{1,2}=4.2 \mathrm{~Hz}, \mathrm{H}-1\right), 4.80(1 \mathrm{H}, \mathrm{d}, \mathrm{H}-2)$, $4.41\left(1 \mathrm{H}\right.$, ddd, $\left.J_{4,5}=9.8 \mathrm{~Hz}, J_{5,6}=5.9 \mathrm{~Hz}, J_{5,6^{\prime}}=4.2 \mathrm{~Hz}, \mathrm{H}-5\right), 4.14$ $\left(1 \mathrm{H}, \mathrm{dd}, J_{6,6^{\prime}}=8.8 \mathrm{~Hz}, \mathrm{H}-6\right), 4.01(1 \mathrm{H}, \mathrm{d}, \mathrm{H}-4), 3.95(1 \mathrm{H}$, dd, H$\left.6^{\prime}\right), 3.51(1 \mathrm{H}, \mathrm{s}, \mathrm{OH}), 1.61,1.47,1.44$, and $1.36(3 \mathrm{H} \times 4$, each s, isop-Me). Found: $\mathrm{C}, 45.26 ; \mathrm{H}, 5.64 \%$. Calcd for $\mathrm{C}_{13} \mathrm{H}_{20} \mathrm{Cl}_{2} \mathrm{O}_{6}$ : C, $45.49 ; \mathrm{H}, 5.87 \%$.

1,2 : 5,6-Di- $O$-isopropylidene-3- $C$-methyl- $\alpha$-D-allofuranose (4). A reaction mixture of $3(33 \mathrm{mg}, 0.096 \mathrm{mmol})$, tributyltin hydride $(280 \mathrm{mg}, 0.96 \mathrm{mmol}, 10 \mathrm{~mol}$ amt.), and AIBN (1.6 $\mathrm{mg}, 0.0098 \mathrm{mmol})$ in dry toluene $\left(3.0 \mathrm{~cm}^{3}\right)$ was refluxed under argon until the disappearance of the 3 on TLC. To the reaction mixture, saturated potassium fluoride solution $\left(5.0 \mathrm{~cm}^{3}\right)$ was added and stirred for $30 \mathrm{~min}$ to produce a precipitate. After the precipitate was filtered off, the separated organic layer was dried over anhydrous magnesium sulfate and evaporated to give a known compound $\mathbf{4}$, which was purified on a column of silica gel (hexane/ethyl acetate $=$ $3 / 1)$. The yield was $87 \%(23 \mathrm{mg})$. The physical constants of 4 were identical to that reported. ${ }^{6)}$

Synthesis of 4 from 6 (Reduction with $\mathrm{LiAlH}_{4}$ ). To a solution of $6(12 \mathrm{mg}, 0.044 \mathrm{mmol})$ in oxolane $\left(5.0 \mathrm{~cm}^{3}\right)$ was added $\mathrm{LiAlH}_{4}(9.0 \mathrm{mg}, 0.24 \mathrm{mmol})$; the mixture was then stirred at room temperature for $1 \mathrm{~h}$. The excess hydride was carefully decomposed with water, and then poured into a saturated aq ammonium chloride solution. The water layer was extracted with chloroform. The combined extract was washed with water, dried over anhydrous magnesium sulfate, and evaporated to give $\mathbf{4}$, which was purified as mentioned above. The yield was $83 \%(10 \mathrm{mg})$.

3,1'-Anhydro-3-C-(1' -chloro-1' - hydroxymethyl)-1,2: 5,6-di$O$-isopropylidene- $\alpha$-D-allofuranose (5). In a similar manner as that mentioned in the synthesis of compound $\mathbf{3}$, the alkoxide intermediate (2) was prepared; the reaction mixture was kept at 65 ${ }^{\circ} \mathrm{C}$ for $15 \mathrm{~min}$, then filtered through a charcoal bed, and evaporated to give 5 , which was purified on a column of silica gel (hexane/ethyl acetate $=4 / 1)$. The yield was $94 \%(291 \mathrm{mg}) .5:$ Syrup; $[\alpha]_{\mathrm{D}}^{24}+49.6^{\circ}$ (c 0.8, $\left.\mathrm{CHCl}_{3}\right)$; ${ }^{1} \mathrm{H}$ NMR $(\mathrm{EX}-90) \delta=5.93\left(1 \mathrm{H}, \mathrm{d}, J_{1,2}=4.2 \mathrm{~Hz}, \mathrm{H}-\right.$ 1), $5.74\left(1 \mathrm{H}, \mathrm{s}, \mathrm{H}-3^{\prime}\right), 4.77(1 \mathrm{H}, \mathrm{d}, \mathrm{H}-2), 4.19-3.85(4 \mathrm{H}, \mathrm{m}, \mathrm{H}-$ $4, \mathrm{H}-5, \mathrm{H}-6$, and $\left.\mathrm{H}-6^{\prime}\right), 1.61,1.43,1.39$, and $1.32(3 \mathrm{H} \times 4$, each s, isop-Me). Found: $\mathrm{C}, 51.24 ; \mathrm{H}, 6.13 \%$. Calcd for $\mathrm{C}_{13} \mathrm{H}_{19} \mathrm{ClO}_{6}$ : C, $50.90 ; \mathrm{H}, 6.24 \%$.

Compound 5 was also derived from 3 by a treatment with DBU in DMSO in $82 \%$ yield, as follows. To a stirring solution of $\mathbf{3}$ (50 $\mathrm{mg}, 0.15 \mathrm{mmol})$ in DMSO $\left(1.0 \mathrm{~cm}^{3}\right)$, DBU $(27 \mathrm{mg}, 0.18 \mathrm{mmol}, 1.2$ mol amt.) was added at room temperature. The reaction mixture was kept for $24 \mathrm{~h}$ at room temperature [there was no change on TLC (hexane/ethyl acetate $=2 / 1$ )], then diluted with ethyl acetate $\left(20 \mathrm{~cm}^{3}\right)$, washed with a saturated aqueous ammonium chloride solution $\left(10 \mathrm{~cm}^{3} \times 1\right)$ and with water $\left(10 \mathrm{~cm}^{3} \times 1\right)$, and evaporated to give a syrup. The syrup was treated on a column of silica gel (hexane/ethyl acetate $=1 / 2$ ) to remove DMSO and DBU; however, the mixture of $\mathbf{5}$ and $\mathbf{3}$ was difficult to separate [only one spot on TLC (hexane/ethyl acetate $=2 / 1$ )]. The mixture of $\mathbf{5}$ and $\mathbf{3}$ was recovered almost quantitatively and ${ }^{1} \mathrm{HNMR}$ data showed that the purity of 5 was $82 \%$. Therefore, the yield of 5 was ca. $82 \%$.

$3,1^{\prime}$-Anhydro-3- $C$ - $\left(1^{\prime}\right.$-hydroxymethyl)-1,2 : 5,6-di- $O$-isopropylidene- $\boldsymbol{\alpha}$-D-allofuranose (6). The reaction mixture of $\mathbf{5}$ (87 $\mathrm{mg}, 0.28 \mathrm{mmol})$, tributyltin hydride $(825 \mathrm{mg}, 2.83 \mathrm{mmol})$, and AIBN (23 mg, $0.14 \mathrm{mmol}$ ) was refluxed (for ca. $1 \mathrm{~h}$ ) under argon until the disappearance of $\mathbf{5}$ on TLC (hexane/ethyl acetate $=1: 1$ ). To the reaction mixture, saturated potassium fluoride solution $(5.0$ $\mathrm{cm}^{3}$ ) was added and stirred for 30 min to produce a precipitate. After the precipitate was filtered off, the separated organic layer was dried over anhydrous magnesium sulfate and evaporated to give 6, which was purified on a column of silica gel (hexane/ethyl acetate $=2 / 1$-ethyl acetate only). The yield was $81 \%(62 \mathrm{mg})$. The structure of 6 was confirmed by comparison of ${ }^{1} \mathrm{HNMR}$ data with that of 3-epimer. ${ }^{7)}$ 6: Syrup; $[\alpha]_{\mathrm{D}}^{25}+82.2^{\circ}\left(\mathrm{c} 0.8, \mathrm{CHCl}_{3}\right)$; ${ }^{1} \mathrm{HNMR}$ $(\mathrm{EX}-270) \delta=5.87\left(1 \mathrm{H}, \mathrm{d}, J_{1,2}=4.0 \mathrm{~Hz}, \mathrm{H}-1\right), 4.43(1 \mathrm{H}, \mathrm{d}, \mathrm{H}-2)$, $4.25\left(1 \mathrm{H}, \mathrm{d}, J_{4.5}=6.9 \mathrm{~Hz}, \mathrm{H}-4\right), 4.09-3.89(3 \mathrm{H}, \mathrm{m}, \mathrm{H}-5, \mathrm{H}-6$, and $\left.\mathrm{H}-6^{\prime}\right), 3.39\left(1 \mathrm{H}, \mathrm{d}, J_{3^{\prime} \mathrm{a}, 3^{\prime} \mathrm{b}}=5.2 \mathrm{~Hz}, \mathrm{H}-3^{\prime} \mathrm{a}\right), 2.97\left(1 \mathrm{H}, \mathrm{d}, \mathrm{H}-3^{\prime} \mathrm{b}\right)$, $1.63,1.41,1.37$, and $1.32(3 \mathrm{H} \times 4$, each $\mathrm{s}$, isop-Me). Found: $\mathrm{C}$, $57.37 ; \mathrm{H}, 7.10 \%$. Calcd for $\mathrm{C}_{13} \mathrm{H}_{20} \mathrm{O}_{6}$ : C, 57.34; $\mathrm{H}, 7.40 \%$.

3-C-Hydroxymethyl-1,2 : 5,6-di- $O$-isopropylidene- $\alpha$-D-allofuranose (7). The reaction mixture of $6(12 \mathrm{mg}, 0.044 \mathrm{mmol})$ and sodium hydroxide ( $18 \mathrm{mg}, 0.45 \mathrm{mmol})$ in a mixed solvent $\left(2 \mathrm{~cm}^{3}, 1\right.$, 4-dioxane- $\mathrm{H}_{2} \mathrm{O}=1 / 1$ ) was refluxed (for $4 \mathrm{~h}$ ) until the disappearance of 6 on TLC (hexane/ethyl acetate $=1 / 1$ ). The reaction mixture was extracted with chloroform $\left(25 \mathrm{~cm}^{3}\right)$, washed with water $(5.0$ $\left.\mathrm{cm}^{3} \times 1\right)$, dried over anhydrous magnesium sulfate, and evaporated to give pure 7 quantitatively $(13 \mathrm{mg})$. 7: Syrup; $[\alpha]_{\mathrm{D}}^{25}+19.0^{\circ}(c$ $\left.1.2, \mathrm{CHCl}_{3}\right)$; IR $3442 \mathrm{~cm}^{-1}(\mathrm{OH}) ;{ }^{1} \mathrm{HNMR}(\mathrm{A}-500) \delta=5.78(1 \mathrm{H}$, d, $\left.J_{1,2}=4.0 \mathrm{~Hz}, \mathrm{H}-1\right), 4.57(1 \mathrm{H}, \mathrm{d}, \mathrm{H}-2), 4.18\left(1 \mathrm{H}, \mathrm{ddd}, J_{4,5}=7.6 \mathrm{~Hz}\right.$, $\left.J_{5,6}=6.4 \mathrm{~Hz}, J_{5,6^{\prime}}=5.8 \mathrm{~Hz}, \mathrm{H}-5\right), 4.09\left(1 \mathrm{H}, \mathrm{dd}, J_{6,6^{\prime}}=8.5 \mathrm{~Hz}, \mathrm{H}-6\right)$, $3.95\left(1 \mathrm{H}, \mathrm{dd}, \mathrm{H}-6^{\prime}\right), 3.91\left(1 \mathrm{H}, \mathrm{dd}, J_{3^{\prime} \mathrm{a}, \mathrm{OH}^{\prime}}=7.6 \mathrm{~Hz}, J_{3^{\prime} \mathrm{a}, 3^{\prime} \mathrm{b}}=11.9\right.$ 
$\left.\mathrm{Hz}, \mathrm{H}^{\prime} 3^{\prime} \mathrm{a}\right), 3.86(1 \mathrm{H}, \mathrm{d}, \mathrm{H}-4), 3.56\left(1 \mathrm{H}, \mathrm{ddd}, J_{3^{\prime} \mathrm{b}, \mathrm{OH}}=0.9 \mathrm{~Hz}\right.$, $\left.J_{3^{\prime} \mathrm{b}, \mathrm{OH}^{\prime}}=8.9 \mathrm{~Hz}, \mathrm{H}-3^{\prime} \mathrm{b}\right), 2.95(1 \mathrm{H}, \mathrm{d}, \mathrm{OH}), 2.44\left(1 \mathrm{H}, \mathrm{dd}, \mathrm{OH}^{\prime}\right)$, $1.60,1.47,1.38$, and $1.36(3 \mathrm{H} \times 4$, each s, isop-Me). Found: $\mathrm{C}$, $53.83 ; \mathrm{H}, 7.51 \%$. Calcd for $\mathrm{C}_{13} \mathrm{H}_{22} \mathrm{O}_{7}$ : $\mathrm{C}, 53.78 ; \mathrm{H}, 7.64 \%$. The configuration of 7 was confirmed by comparison of ${ }^{1} \mathrm{HNMR}$ data with that of 3-epimer. . $^{8}$

Synthesis of 7 from 11 (Hydrolysis with Aqueous $\mathrm{NaOH}$ ). The reaction mixture of $\mathbf{1 1}(50 \mathrm{mg}, 0.16 \mathrm{mmol})$ and sodium hydroxide $(65 \mathrm{mg}, 1.6 \mathrm{mmol})$ in a mixed solvent $\left(16 \mathrm{~cm}^{3}, 1,4-\right.$ dioxane $/ \mathrm{H}_{2} \mathrm{O}=1 / 1$ ) was refluxed (for $12 \mathrm{~h}$ ) until the disappearance of 11 on TLC (hexane/ethyl acetate $=1 / 1$ ). The reaction mixture was evaporated to ca. a half volume and extracted with chloroform $\left(25 \mathrm{~cm}^{3}\right)$. The extract was washed with water $\left(5.0 \mathrm{~cm}^{3} \times 1\right)$, dried over anhydrous magnesium sulfate, and evaporated to give pure 7 (33 mg). The yield was $70 \%$.

3-Azido-3-deoxy-3- $C$-formyl-1,2 : 5,6-di- $O$-isopropylidene- $\alpha$ D-glucofuranose (8). The reaction mixture of $\mathbf{3}$ (100 $\mathrm{mg}, 0.29$ mmol), sodium azide $(190 \mathrm{mg}, 2.92 \mathrm{mmol})$, and 15 -crown-5 $(40 \mathrm{mg})$ in HMPT $\left(2.0 \mathrm{~cm}^{3}\right)$ was stirred at $70^{\circ} \mathrm{C}$ for $3.5 \mathrm{~h}$ under argon until the disappearance of $\mathbf{3}$ on TLC (hexane/ethyl acetate $=2 / 1$ ). The reaction mixture was diluted with toluene, washed with water, dried over anhydrous magnesium sulfate, and evaporated to give $\mathbf{8}$, which was purified on a column of silica gel (hexane/ethyl acetate $=1 / 4$ ). The yield was $81 \%(74 \mathrm{mg})$. In a similar way to that mentioned above, compound $\mathbf{8}$ was also obtained from $\mathbf{5}$ in $85 \%$ yield. 8 : Syrup; $[\alpha]_{\mathrm{D}}^{24}+76.9^{\circ}\left(c 1.8, \mathrm{CHCl}_{3}\right) ; \mathrm{IR} 2120 \mathrm{~cm}^{-1}\left(\mathrm{~N}_{3}\right)$ and 1736 $\mathrm{cm}^{-1}(\mathrm{C}=\mathrm{O}) ;{ }^{1} \mathrm{H} N M R(\mathrm{FX}-200) \delta=9.67(1 \mathrm{H}, \mathrm{s}, \mathrm{CHO}), 5.94(1 \mathrm{H}$, d, $\left.J_{1,2}=3.4 \mathrm{~Hz}, \mathrm{H}-1\right), 4.63(1 \mathrm{H}, \mathrm{d}, \mathrm{H}-2), 4.55\left(1 \mathrm{H}, \mathrm{d}, J_{4,5}=8.5 \mathrm{~Hz}\right.$, $\mathrm{H}-4), 4.23\left(1 \mathrm{H}\right.$, ddd, $\left.J_{5,6}=3.7 \mathrm{~Hz}, J_{5,6^{\prime}}=5.9 \mathrm{~Hz}, \mathrm{H}-5\right), 4.15(1 \mathrm{H}$, dd, $\left.J_{6,6^{\prime}}=8.6 \mathrm{~Hz}, \mathrm{H}-6^{\prime}\right), 4.04(1 \mathrm{H}, \mathrm{dd}, \mathrm{H}-6), 1.61,1.38,1.33$, and 1.31 ( $3 \mathrm{H} \times 4$, each s, isop-Me). Found: $\mathrm{C}, 50.04 ; \mathrm{H}, 6.31 ; \mathrm{N}, 13.30 \%$. Calcd for $\mathrm{C}_{13} \mathrm{H}_{19} \mathrm{~N}_{3} \mathrm{O}_{6}: \mathrm{C}, 49.83 ; \mathrm{H}, 6.11 ; \mathrm{N}, 13.41 \%$.

3-Deoxy-3- $C$-hydroxymethyl-1,2:5,6-di- $O$-isopropylidene$\boldsymbol{\alpha}$-D-allofuranose (9). The reaction mixture of $3(50 \mathrm{mg}, 0.15$ mmol) and $\mathrm{NaBH}_{4}(56 \mathrm{mg}, 1.5 \mathrm{mmol})$ in DMSO $\left(0.5 \mathrm{~cm}^{3}\right)$ was stirred at $80^{\circ} \mathrm{C}$ until the disappearance of 3 on TLC (for $18 \mathrm{~h}$ ). The reaction mixture was poured into brine, extracted with ethyl acetate, washed with water, dried over anhydrous magnesium sulfate, and evaporated to give 9 , which was purified on a column of silica gel (hexane/ethyl acetate $=5 / 1)$. The yield was $65 \%(27 \mathrm{mg})$. 9: Syrup; $[\alpha]_{\mathrm{D}}^{24}+32.7^{\circ}\left(\mathrm{c} 2.0, \mathrm{CHCl}_{3}\right) ;$ IR $3490 \mathrm{~cm}^{-1}(\mathrm{OH}) ;{ }^{1} \mathrm{H}$ NMR (FX200) $\delta=5.74\left(1 \mathrm{H}, \mathrm{d}, J_{1,2}=3.7 \mathrm{~Hz}, \mathrm{H}-1\right), 4.75\left(1 \mathrm{H}, \mathrm{dd}, J_{2,3}=4.6\right.$ $\mathrm{Hz}, \mathrm{H}-2), 4.21-3.80\left(6 \mathrm{H}, \mathrm{m}, \mathrm{H}-3^{\prime} \mathrm{a}, \mathrm{H}-3^{\prime} \mathrm{b}, \mathrm{H}-4, \mathrm{H}-5, \mathrm{H}-6\right.$, and $\mathrm{H}-$ $\left.6^{\prime}\right), 3.28(1 \mathrm{H}, \mathrm{m}, \mathrm{OH}), 2.12(1 \mathrm{H}, \mathrm{m}, \mathrm{H}-3), 1.52,1.45,1.37$, and 1.31 $(3 \mathrm{H} \times 4$, each s, isop-Me). Found: $\mathrm{C}, 57.13 ; \mathrm{H}, 8.28 \%$. Calcd for $\mathrm{C}_{13} \mathrm{H}_{22} \mathrm{O}_{6}: \mathrm{C}, 56.92 ; \mathrm{H}, 8.08 \%$.

Synthesis of 9 from 10 (Reduction with Tributyltin Hydride and $\mathrm{NaBH}_{4}$ ). The reaction mixture of $\mathbf{1 0}(68 \mathrm{mg}, 0.22 \mathrm{mmol}$ ), tributyltin hydride $(323 \mathrm{mg}, 1.11 \mathrm{mmol}, 5.0 \mathrm{~mol}$ amt.), and AIBN (18 mg, $0.11 \mathrm{mmol}, 0.5 \mathrm{~mol}$ amt.) in toluene $\left(5.0 \mathrm{~cm}^{3}\right)$ was refluxed (for ca. $30 \mathrm{~min}$ ) under argon until the disappearance of $\mathbf{1 0}$ on TLC (hexane/ethyl acetate $=2 / 1$ ). After the reaction mixture was separated on a preparative TLC (hexane/ethyl acetate $=2 / 1$ ) to give the corresponding dechlorinated compound, the product was immediately reduced with $\mathrm{NaBH}_{4}(56 \mathrm{mg}, 1.5 \mathrm{mmol})$ at room temperature in methanol $\left(5.0 \mathrm{~cm}^{3}\right)$. The reaction mixture was evaporated, extracted with ethyl acetate, washed with water, and dried over anhydrous magnesium sulfate; the organic layer was then evaporated to give 9 , which was purified on a column of silica gel (hexane/ethyl acetate $=5 / 1$ ). The yield was $82 \%$ ( 2 steps, $50 \mathrm{mg}$ ). The physical constants were identical to those mentioned above.

Acetyl Derivative of 9. The reaction mixture of $9(26 \mathrm{mg}$,
$0.095 \mathrm{mmol})$ and acetic anhydride $\left(1.0 \mathrm{~cm}^{3}\right)$ in pyridine $\left(1.0 \mathrm{~cm}^{3}\right)$ was stirred at room temperature until the disappearance of 9 on TLC. To the reaction mixture, ethanol and toluene were added and coevaporated to give the corresponding acetyl derivative in quantitative yield (30 mg). Syrup; $[\alpha]_{D}^{24}+74.3^{\circ}\left(c 0.9, \mathrm{CHCl}_{3}\right)$; IR $1746 \mathrm{~cm}^{-1}(\mathrm{C}=\mathrm{O}){ }^{1}{ }^{1} \mathrm{H}$ NMR $(\mathrm{FX}-200) \delta=5.80\left(1 \mathrm{H}, \mathrm{d}, J_{1,2}=3.7\right.$ $\mathrm{Hz}, \mathrm{H}-1), 4.72\left(1 \mathrm{H}, \mathrm{dd}, J_{2,3}=4.6 \mathrm{~Hz}, \mathrm{H}-2\right), 4.50\left(1 \mathrm{H}, \mathrm{dd}, J_{3,3^{\prime} \mathrm{a}}=4.9\right.$ $\left.\mathrm{Hz}, J_{3^{\prime} \mathrm{a}, 3^{\prime} \mathrm{b}}=11.0 \mathrm{~Hz}, \mathrm{H}-3^{\prime} \mathrm{a}\right), 4.21\left(1 \mathrm{H}, \mathrm{dd}, J_{3,3^{\prime} \mathrm{b}}=11.0 \mathrm{~Hz}, \mathrm{H}-3^{\prime} \mathrm{b}\right)$, $4.18-3.82\left(3 \mathrm{H}, \mathrm{m}, \mathrm{H}-5, \mathrm{H}-6\right.$, and $\left.\mathrm{H}-6^{\prime}\right), 3.78\left(1 \mathrm{H}, \mathrm{dd}, J_{3,4}=10.0\right.$ $\mathrm{Hz}, \mathrm{H}-4), 2.27$ (1H, dddd, $\mathrm{H}-3$ ), 2.08 (3H, s, OAc), 1.52, 1.41, 1.34, and $1.34(3 \mathrm{H} \times 4$, each $\mathrm{s}$, isop-Me). Found: $\mathrm{C}, 57.33 ; \mathrm{H}, 7.64 \%$. Calcd for $\mathrm{C}_{15} \mathrm{H}_{24} \mathrm{O}_{7}$ : C, $56.95 ; \mathrm{H}, 7.65 \%$.

3-Chloro-3-deoxy-3- $C$-formyl-1,2 : 5,6-di- $O$-isopropylidene$\alpha$-D-glucofuranose (10). The reaction mixture of 3 (100 $\mathrm{mg}, 0.29$ $\mathrm{mmol}), \mathrm{NaOAc}(239 \mathrm{mg}, 2.91 \mathrm{mmol})$, and 15 -crown-5 $(40 \mathrm{mg})$ in HMPT $\left(2.0 \mathrm{~cm}^{3}\right)$ was stirred at $70^{\circ} \mathrm{C}$ under argon for $24 \mathrm{~h}$ until the disappearance of 3 . The reaction mixture was directly separated on a column of silica gel (hexane/ethyl acetate $=1 / 3$ ) to give 10, which easily formed its hydrate and was too unstable to purify. The yield was $83 \%$ (74 mg). Therefore, only IR and ${ }^{1} \mathrm{H}$ NMR data were measured, as described below. 10: Syrup; IR $1740 \mathrm{~cm}^{-1}(\mathrm{C}=0)$; ${ }^{1} \mathrm{HNMR}(\mathrm{FX}-200) \delta=9.60(1 \mathrm{H}, \mathrm{s}, \mathrm{CHO}), 5.99\left(1 \mathrm{H}, \mathrm{d}, J_{1,2}=3.4\right.$ $\mathrm{Hz}, \mathrm{H}-1), 4.80(1 \mathrm{H}, \mathrm{d}, \mathrm{H}-2), 4.67\left(1 \mathrm{H}, \mathrm{d}, J_{4,5}=8.1 \mathrm{~Hz}, \mathrm{H}-4\right), 4.30$ $\left(1 \mathrm{H}, \mathrm{ddd}, J_{5,6}=5.6 \mathrm{~Hz}, J_{5,6^{\prime}}=4.4 \mathrm{~Hz}, \mathrm{H}-5\right), 4.15\left(1 \mathrm{H}, \mathrm{dd}, J_{6,6^{\prime}}=9.0\right.$ $\mathrm{Hz}, \mathrm{H}-6), 4.09\left(1 \mathrm{H}, \mathrm{dd}, \mathrm{H}-6^{\prime}\right), 1.59,1.38,1.33$, and $1.31(3 \mathrm{H} \times 4$, each $\mathrm{s}$, isop-Me). A further confirmation of the structure of $\mathbf{1 0}$ was achieved by derivation into the corresponding hydroxymethyl derivative (11), as follows.

3-Chloro-3-deoxy-3- $C$-hydroxymethyl-1,2 : 5,6-di- $O$-isopropylidene- $\boldsymbol{\alpha}$-D-glucofuranose (11). To a solution of $\mathbf{1 0}(50 \mathrm{mg}$, $0.16 \mathrm{mmol})$ in methanol $\left(2.0 \mathrm{~cm}^{3}\right)$ was added $\mathrm{NaBH}_{4}(61 \mathrm{mg}, 1.6$ $\mathrm{mmol})$ in water $\left(1.0 \mathrm{~cm}^{3}\right)$ and stirred at room temperature until the disappearance of $\mathbf{1 0}$ on TLC. The reaction mixture was poured into brine, extracted with chloroform, washed with water, dried over anhydrous magnesium sulfate, and evaporated to give 11, which was purified on a column of silica gel (hexane/ethyl acetate $=1 / 1$ ). The yield was $97 \%(49 \mathrm{mg})$. 11: Syrup; $[\alpha]_{\mathrm{D}}^{25}+22.4^{\circ}\left(\mathrm{c} 1.1, \mathrm{CHCl}_{3}\right)$; IR $3472 \mathrm{~cm}^{-1}(\mathrm{OH}) ;{ }^{1} \mathrm{H}$ NMR (FX-200) $\delta=5.89\left(1 \mathrm{H}, \mathrm{d}, J_{1,2}=3.5\right.$ $\mathrm{Hz}, \mathrm{H}-1), 4.74(1 \mathrm{H}, \mathrm{d}, \mathrm{H}-2), 4.46-3.96\left(6 \mathrm{H}, \mathrm{m}, \mathrm{H}-3^{\prime} \mathrm{a}, \mathrm{H}-3^{\prime} \mathrm{b}, \mathrm{H}-\right.$ $4, \mathrm{H}-5, \mathrm{H}-6$, and $\left.\mathrm{H}-6^{\prime}\right), 1.54,1.44,1.36$, and $1.34(3 \mathrm{H} \times 4$, each s, isop-Me). Found: $\mathrm{C}, 50.19 ; \mathrm{H}, 6.55 \%$. Calcd for $\mathrm{C}_{13} \mathrm{H}_{21} \mathrm{ClO}_{6}$ : $\mathrm{C}$, $50.57 ; \mathrm{H}, 6.86 \%$.

Acetyl Derivative of 11 . The reaction mixture of $\mathbf{1 1}(10 \mathrm{mg}$, $0.032 \mathrm{mmol})$ and acetic anhydride $\left(0.5 \mathrm{~cm}^{3}\right)$ in pyridine $\left(0.5 \mathrm{~cm}^{3}\right)$ was stirred at room temperature until the disappearance of $\mathbf{1 1}$ on TLC. To the reaction mixture, ethanol and toluene were added and coevaporated to give the corresponding acetoxymethyl derivative in quantitative yield (12 mg). Syrup; $[\alpha]_{\mathrm{D}}^{25}+29.6^{\circ}\left(c 1.5, \mathrm{CHCl}_{3}\right)$; IR $1746 \mathrm{~cm}^{-1}(\mathrm{C}=\mathrm{O})$; $^{~} \mathrm{H}$ NMR (FX-200) $\delta=5.87\left(1 \mathrm{H}, \mathrm{d}, J_{1,2}=3.2\right.$ $\mathrm{Hz}, \mathrm{H}-1), 4.71$ and $4.32\left(1 \mathrm{H} \times 2, \mathrm{ABq}, J_{\mathrm{A}, \mathrm{B}}=12.2 \mathrm{~Hz}, \mathrm{H}-3^{\prime} \mathrm{a}\right.$ and $\mathrm{H}-$ $\left.3^{\prime} \mathrm{b}\right), 4.36\left(1 \mathrm{H}\right.$, ddd, $\left.J_{4,5}=8.4 \mathrm{~Hz}, J_{5,6}=6.4 \mathrm{~Hz}, J_{5,6^{\prime}}=4.4 \mathrm{~Hz}, \mathrm{H}-5\right)$, $4.11\left(1 \mathrm{H}, \mathrm{dd}, J_{6,6^{\prime}}=9.3 \mathrm{~Hz}, \mathrm{H}-6\right), 4.01\left(1 \mathrm{H}, \mathrm{dd}, \mathrm{H}-6^{\prime}\right), 3.91(1 \mathrm{H}, \mathrm{d}$, $\mathrm{H}-4), 2.12(3 \mathrm{H}, \mathrm{s}, \mathrm{OAc}), 1.51,1.41,1.32$, and $1.32(3 \mathrm{H} \times 4$, each s, isop-Me). Found: $\mathrm{C}, 51.69 ; \mathrm{H}, 6.38 \%$. Calcd for $\mathrm{C}_{15} \mathrm{H}_{23} \mathrm{ClO}_{7}$ : $\mathrm{C}$, $51.36 ; \mathrm{H}, 6.61 \%$.

3-C-Formyl-1,2: 5,6-di- $O$-isopropylidene- $\alpha$-D-glucofuranose (12). The reaction mixture of $3(100 \mathrm{mg}, 0.29 \mathrm{mmol})$, CsOAc (560 mg, $2.92 \mathrm{mmol}, 10 \mathrm{~mol}$ amt.), and 18-crown-6 (550 mg, 2.08 mmol, $7.0 \mathrm{~mol} \mathrm{amt}$.) in dry toluene $\left(5 \mathrm{~cm}^{3}\right)$ was refluxed for $5 \mathrm{~h}$ until the disappearance of $\mathbf{3}$ on TLC (hexane/ethyl acetate $=3 / 1$ ). The reaction mixture was then poured into a saturated aqueous ammonium chloride solution $\left(20 \mathrm{~cm}^{3}\right)$, extracted with ethyl acetate ( 3 times), 
washed with brine and water, dried over anhydrous magnesium sulfate, filtered, and evaporated to give a syrupy product, which was separated on a preparative TLC (hexane/ethyl acetate $=5 / 1$ ) to give 12. The yield was $30 \mathrm{mg}$ (36\%). Compound $\mathbf{1 2}$ easily formed its hydrate, and was too unstable to purify. Therefore, only IR and ${ }^{1} \mathrm{HNMR}$ data were measured, as described below. 12: Syrup; IR $3460(\mathrm{OH})$ and $1730 \mathrm{~cm}^{-1}(\mathrm{C}=\mathrm{O})$; ${ }^{1} \mathrm{H}$ NMR $(\mathrm{EX}-270) \delta=9.76$ $\left(1 \mathrm{H}, \mathrm{d}, J_{\mathrm{CHO}, \mathrm{OH}}=1.0 \mathrm{~Hz}, \mathrm{CHO}\right), 5.93\left(1 \mathrm{H}, \mathrm{d}, J_{1,2}=3.3 \mathrm{~Hz}, \mathrm{H}-1\right)$, $4.49\left(1 \mathrm{H}, \mathrm{d}, J_{4,5}=8.9 \mathrm{~Hz}, \mathrm{H}-4\right), 4.45(1 \mathrm{H}, \mathrm{d}, \mathrm{H}-2), 4.25(1 \mathrm{H}$, ddd, $\left.J_{5,6}=5.9 \mathrm{~Hz}, J_{5,6^{\prime}}=4.3 \mathrm{~Hz}, \mathrm{H}-5\right), 4.11\left(1 \mathrm{H}, \mathrm{dd}, J_{6,6^{\prime}}=8.9 \mathrm{~Hz}, \mathrm{H}-6\right)$, $4.06\left(1 \mathrm{H}, \mathrm{dd}, \mathrm{H}-6^{\prime}\right), 3.76(1 \mathrm{H}, \mathrm{d}, \mathrm{OH}), 1.61,1.35,1.32$, and 1.27 ( $3 \mathrm{H} \times 4$, each $\mathrm{s}$, isop-Me).

3-C-Hydroxymethyl-1,2 : 5,6-di- $O$-isopropylidene- $\alpha$-D-glucofuranose (13). The reaction mixture of $12(30 \mathrm{mg}, 0.10 \mathrm{mmol})$ and $\mathrm{NaBH}_{4}$ (39 mg, $1.0 \mathrm{mmol}, 10 \mathrm{~mol}$ amt.) in methanol $\left(5.0 \mathrm{~cm}^{3}\right)$ was stirred at room temperature for $1 \mathrm{~h}$. It was then partially evaporated after the addition of a saturated ammonium chloride solution, extracted with chloroform, washed with water, dried over anhydrous magnesium sulfate, and evaporated to give $\mathbf{1 3}$ in quantitative yield $(31 \mathrm{mg})$, of which the physical data were identical with that reported. ${ }^{8)}$

3-C-Formyl-1,2 : 5,6-di- $O$-isopropylidene- $\alpha$-D-allofuranose (14). To a solution of $3(100 \mathrm{mg}, 0.29 \mathrm{mmol})$ in DMSO (7.0 $\mathrm{cm}^{3}$ ) was added tetrabutylammonium hydroxide (40 wt \% solution in water, $1.0 \mathrm{~cm}^{3}, 1.5 \mathrm{mmol}, 5.2 \mathrm{~mol} \mathrm{amt}$.) at room temperature; the reaction mixture was kept for a very short time until the disappearance of $3(30 \mathrm{~s})$. It was poured into a saturated aqueous ammonium chloride solution $\left(20 \mathrm{~cm}^{3}\right)$, extracted with ethyl acetate ( 3 times), washed with brine and water, dried over anhydrous magnesium sulfate, and evaporated to give a syrupy product, which was separated on a preparative TLC (hexane/ethyl acetate $=3 / 1$ ) to give 14 . The yield was $61 \%(51 \mathrm{mg})$. Compound $\mathbf{1 4}$ easily formed its hydrate and was too unstable to purify. Therefore, only IR and ${ }^{1} \mathrm{H}$ NMR data were measured, as described below. 14: Syrup; IR $3488 \mathrm{~cm}^{-1}$ $(\mathrm{OH})$ and $1730 \mathrm{~cm}^{-1}(\mathrm{C}=\mathrm{O})$; 'H NMR (EX-270) $\delta=9.81(1 \mathrm{H}, \mathrm{s}$, CHO), $5.95\left(1 \mathrm{H}, \mathrm{d}, J_{1,2}=3.9 \mathrm{~Hz}, \mathrm{H}-1\right), 4.45(1 \mathrm{H}, \mathrm{d}, \mathrm{H}-2), 4.23(1 \mathrm{H}$, ddd, $\left.J_{4,5}=6.3 \mathrm{~Hz}, J_{5,6}=6.3 \mathrm{~Hz}, J_{5,6^{\prime}}=6.3 \mathrm{~Hz}, \mathrm{H}-5\right), 4.11(1 \mathrm{H}, \mathrm{d}, \mathrm{H}-$ 4), $4.07\left(1 \mathrm{H}, \mathrm{dd}, J_{6,6^{\prime}}=8.6 \mathrm{~Hz}, \mathrm{H}-6\right), 3.96\left(1 \mathrm{H}, \mathrm{dd}, \mathrm{H}-6^{\prime}\right), 3.53(1 \mathrm{H}$, $\mathrm{s}, \mathrm{OH}), 1.62,1.44,1.39$, and $1.33(3 \mathrm{H} \times 4$, each s, isop-Me).

Reduction of 14 with $\mathrm{NaBH}_{4}$ into 7 . The reaction mixture of 14 (50 mg, $0.17 \mathrm{mmol}$ ) and $\mathrm{NaBH}_{4}(66 \mathrm{mg}, 1.7 \mathrm{mmol}, 10 \mathrm{~mol} \mathrm{amt}$ ) in methanol $\left(5.0 \mathrm{~cm}^{3}\right)$ was stirred at room temperature for $1 \mathrm{~h}$. It was then partially evaporated after the addition of saturated ammonium chloride solution, extracted with chloroform, washed with water, dried over anhydrous magnesium sulfate, and evaporated to give 7 in quantitative yield $(50 \mathrm{mg})$. The physical data were identical to that obtained from $\mathbf{6}$ or $\mathbf{1 1}$.

3- $C$-Dimethoxymethyl-1,2 : 5,6-di- $O$-isopropylidene- $\alpha$-D-allofuranose (15). To a solution of $3(33 \mathrm{mg}, 0.096 \mathrm{mmol})$ in HMPT $\left(1.0 \mathrm{~cm}^{3}\right)$ was added a solution of sodium methoxide (sodium $22 \mathrm{mg}$, $0.96 \mathrm{mmol}$ in methanol $1.0 \mathrm{~cm}^{3}$ ) and stirred at $70^{\circ} \mathrm{C}$ under argon for $24 \mathrm{~h}$ until the disappearance of 3 on TLC. The reaction mixture was directly purified on a column of silica gel (ether only) to give $\mathbf{1 5}$ in $93 \%$ yield $(30 \mathrm{mg}) .15: \mathrm{Mp} 89.0-90.5^{\circ} \mathrm{C}$ (recrystallized from ether-hexane); $[\alpha]_{\mathrm{D}}^{24}+3.9^{\circ}\left(\mathrm{c} 0.6, \mathrm{CHCl}_{3}\right)$; IR $3520 \mathrm{~cm}^{-1}(\mathrm{OH})$; ${ }^{1} \mathrm{H} \mathrm{NMR}(\mathrm{FX}-200) \delta=5.71\left(1 \mathrm{H}, \mathrm{d}, J_{1,2}=3.8 \mathrm{~Hz}, \mathrm{H}-1\right), 4.61(1 \mathrm{H}, \mathrm{d}$, $\mathrm{H}-2), 4.54\left(1 \mathrm{H}, \mathrm{s}, \mathrm{H}-3^{\prime}\right), 4.22\left(1 \mathrm{H}, \mathrm{ddd}, J_{4,5}=8.3 \mathrm{~Hz}, J_{5,6}=4.4 \mathrm{~Hz}\right.$, $\left.J_{5,6^{\prime}}=6.1 \mathrm{~Hz}, \mathrm{H}-5\right), 4.10\left(1 \mathrm{H}, \mathrm{dd}, J_{6,6^{\prime}}=8.8 \mathrm{~Hz}, \mathrm{H}-6^{\prime}\right), 3.93(1 \mathrm{H}, \mathrm{dd}$, H-6), $3.92(1 \mathrm{H}, \mathrm{d}, \mathrm{H}-4), 3.66$ and 3.47 ( $3 \mathrm{H} \times 2$, each s, OMe $\times 2)$, $2.90(1 \mathrm{H}, \mathrm{s}, \mathrm{OH}), 1.58,1.46,1.38$, and $1.37(3 \mathrm{H} \times 4$, each $\mathrm{s}$, isopMe). Found: $\mathrm{C}, 53.87 ; \mathrm{H}, 7.88 \%$. Calcd for $\mathrm{C}_{15} \mathrm{H}_{26} \mathrm{O}_{8}$ : C, 53.88; $\mathrm{H}, 7.84 \%$.

\section{References}

1) J. Yoshimura, Adv. Carbohydr. Chem. Biochem., 42, 69 (1984).

2) T. T. Thang, M. A. Laborde, A. Olesker, and G. Lukacs, J. Chem. Soc., Chem. Commun., 1988, 1581.

3) G. Köbrich and W. Werner, Tetrahedron Lett., 1969, 2181.

4) K. Sato, K. Suzuki, M. Ueda, M. Katayama, and Y. Kajihara, Chem. Lett., 1991, 1469.

5) J. Yoshimura, K. Sato, and H. Hashimoto, Chem. Lett., 1977, 1327.

6) J. S. Brimacombe, A. J. Rollins, S. W. Thompson, and S. N. Mikahilov, J. Carbohydr. Nucleosides Nucleotides, 6, 237 (1979).

7) D. C. Baker, D. K. Brown, D. Horton, and R. G. Nikol, Carbohydr. Res., 32, 299 (1974).

8) Epimer of compound 7 (13): J. Yoshimura, K. Kobayashi, K. Sato, and M. Funabashi, Bull. Chem. Soc. Jpn., 45, 1806 (1972).

9) A. Kirrmann, P. Duhamel, and R. Nouri-Bimorghi, Justus Liebigs Ann. Chem., 691, 33 (1966).

10) a) Y. Torisawa, H. Okabe, and S. Ikegami, Chem. Lett., 1984, 1555; b) W. H. Kruizinga, B. Strijtveen, and R. M. Kellogg, J. Org. Chem., 46, 4321 (1981).

11) a) K. Sato, K. Suzuki, and Y. Hashimoto, Chem. Lett., 1995 , 83; b) K. Sato, Y. Yamamoto, and H. Hori, Tetrahedron Lett., 1996, 2799 . 